\title{
Meta-analysis of frusemide to prevent or treat acute renal failure
}

\author{
Kwok M Ho, David J Sheridan
}

\begin{abstract}
Objective To investigate the potential beneficial and adverse effects of frusemide to prevent or treat acute renal failure in adults.

Design Meta-analysis of randomised controlled trials.

Data sources Cochrane controlled trials register (2005 issue 4), Embase, and Medline (1966 to 1 February 2006), without language restrictions.

Review methods Two reviewers checked the quality of the studies and independently extracted data.

Results Nine randomised controlled trials totalling 849 patients with or at risk of acute renal failure were included. Outcome measures not significantly different after frusemide treatment were in-hospital mortality (relative risk $1.11,95 \%$ confidence interval 0.92 to 1.33), risk for requiring renal replacement therapy or dialysis $(0.99,0.80$ to 1.22$)$, number of dialysis sessions required (weight mean difference -0.48 sessions, -1.45 to 0.50 ), and proportion of patients with persistent oliguria (urine output $<500 \mathrm{ml}$ /day: $0.54,0.18$ to 1.61 ). Stratifying studies that used frusemide to prevent or treat acute renal failure did not change the results on mortality (relative risk ratio $2.10,95 \%$ confidence interval 0.67 to 6.63 ) and the risk for requiring dialysis (4.12, 0.46 to 37.2$)$. Evidence suggested an increased risk of temporary deafness and tinnitus in patients treated with high doses of frusemide (relative risk $3.97,95 \%$ confidence interval 1.00 to 15.78 ).

Conclusions Frusemide is not associated with any significant clinical benefits in the prevention and treatment of acute renal failure in adults. High doses may be associated with an increased risk of ototoxicity.
\end{abstract}

\section{Introduction}

Acute renal failure is associated with a significant risk of mortality and morbidity. ${ }^{1}$ The causes of acute renal failure include sepsis, hypovolaemia, pre-existing renal impairment, and nephrotoxins such as aminoglycoside antibiotics and radiological contrast agents. $^{12}$

Loop diuretics reduce the energy requirement of the cells of the thick limb of the loop of Henle by inhibiting the sodium-chloride-potassium pump in the luminal cell membrane. They have also been shown to reduce renal medullary damage during hypoxic conditions in isolated perfused kidney. ${ }^{3} 4$ Non-oliguric acute renal failure is associated with a better prognosis than oliguric acute renal failure. ${ }^{5}$ Some clinicians therefore use high doses of loop diuretics to convert oliguric renal failure to non-oliguric renal failure to facilitate fluid and electrolyte management and to reduce the need for dialysis. Nevertheless, several small randomised controlled studies evaluating the use of frusemide to either prevent or treat acute renal failure have pro- duced negative results. ${ }^{\text {w1-w4 }}$ Furthermore, the use of diuretics for acute renal failure has also been associated with an increased risk of non-recovery of renal function and mortality. ${ }^{6}$

No large randomised controlled trials or meta-analyses have evaluated the role of frusemide in acute renal failure. Frusemide is frequently used to facilitate fluid and electrolyte management of acute renal failure in many institutions, ${ }^{2}$ yet its potential benefits, adverse effects, and cost effectiveness to prevent or treat acute renal failure remain uncertain. We carried out a meta-analysis to assess the potential beneficial and harmful effects of frusemide in acute renal failure and whether effects differ when used to prevent or to treat acute renal failure.

\section{Methods}

We searched the Cochrane controlled trials register (2005 issue 4), Embase, and Medline (1966 to 1 February 2006) for randomised controlled clinical trials comparing frusemide with placebo in adults using the exploded MeSH terms "frusemide", "furosemide", "loop diuretic", or "lasix" with "renal failure", "renal impairment", "dialysis", "renal support", "hemodiafiltration", "hemofiltration", "hemodialysis", or "renal replacement therapy". We also included studies of single dose frusemide compared with prolonged continuous infusion. We excluded studies comparing two different modes of frusemide administration such as regular boluses with continuous infusions. As the causes and treatment of acute renal failure in children differ from those in adults we excluded studies of children only.

The search was further limited to clinical trials, letters, and randomised controlled trials. We also searched the reference lists of related reviews and original articles for relevant trials. To ensure that all suitable studies were included we also searched the websites of the International Network of Agencies of Health Technology Assessment and International Society of Technology Assessment in Health Care. We found no studies published that were not in English.

Two reviewers (KMH, DJS) independently examined the titles and abstracts of all identified trials to confirm fulfilment of inclusion criteria. They recorded the trial characteristics and outcomes independently, using a predesigned data abstraction form. This form was used to record information on the quality of the trial such as allocation concealment, method of randomisation, blinding, and inclusion and exclusion criteria. The Jadad scale was used to score study quality (range 0-5, higher scales indicating better quality $)^{7}$ but the component that constituted the quality of the study including blinding, allocation concealment, and intention to treat analysis were also described. Grading of

References w1-w22 are on bmj.com 
allocation concealment was based on the Cochrane approach (adequate, uncertain, clearly inadequate). No disagreements occurred between the reviewers on data extracted. One study published data in two publications. ${ }^{8}{ }^{5}$ We combined these data to represent one trial. Data were checked and entered into RevMan version 4.2 (Cochrane Collaboration, 2003) for further analyses.

We chose in-hospital mortality and the proportion of patients requiring renal dialysis or replacement therapy as the main outcomes for meta-analysis because they are the most relevant clinical outcomes in patients with acute renal failure. No data were missing for these two outcomes in the included studies. The other outcomes assessed were the proportion of patients remaining oliguric (urine output $<500 \mathrm{ml} /$ day), proportion of patients who developed ototoxicity, number of dialysis sessions required until recovery, and length of hospital stay.

\section{Statistical analyses}

Using a random effect model we report the differences in categorical outcomes between the treatment and placebo or control groups as relative risks with $95 \%$ confidence intervals. We further stratified the effects of frusemide on mortality and the need for dialysis after frusemide treatment into studies using frusemide to prevent or to treat acute renal failure, and we tested this interaction by relative risk ratio. ${ }^{9}$ Using a random effect model we report the differences in length of hospital stay and the number of dialysis sessions required as weighted mean differences. We used the $\chi^{2}$ statistic to assess heterogeneity between trials and the $\mathrm{I}^{2}$ statistic to assess the extent of inconsistency. ${ }^{10}$ One study reported tinnitus and deafness in several patients after frusemide treatment but did not specify the number. ${ }^{\mathrm{w} 5}$ We therefore estimated that at least three patients would have tinnitus or deafness in the frusemide group. One study reported the duration of continuous renal replacement therapy until recovery. ${ }^{\mathrm{w4}}$ We pooled the results of this study with others that reported the total number of dialysis sessions required until recovery of renal function. We carried out sensitivity analyses by excluding one study that compared a single dose of frusemide with prolonged continuous infusion ${ }^{w 6}$ or by including only studies that had adequate allocation concealment. ${ }^{\text {w1-w3 } 37}$ Publication bias was assessed by funnel plot using mortality as an end point. We considered a $P$ value less than 0.05 as significant.

\section{Results}

Nine of 23 potentially eligible studies, ${ }^{\text {w1-w9 }}$ totalling 849 patients, were subject to meta-analysis (fig 1). Three studies used frusemide to prevent acute renal failure ${ }^{\mathrm{w1}-\mathrm{w} 3}$ and six used frusemide to treat acute renal failure. ${ }^{\mathrm{w}-\mathrm{w} 9}$ The three preventive studies included patients who underwent cardiac surgery, cardiac angiography, and major general or vascular surgery. In two of these studies all participants had mild pre-existing renal impairment. ${ }^{\mathrm{w} 1} \mathrm{w}^{2}$ Five of the six treatment studies included patients with acute renal failure without chronic renal failure and one study included patients who had either acute renal failure or acute on chronic renal failure. ${ }^{\mathrm{w}}$

The treatment protocol varied between studies. Doses of frusemide used to prevent acute renal failure were $1 \mathrm{mg} / \mathrm{h}$ or 2.5 $\mathrm{mg} / \mathrm{h}$ by intravenous infusion ${ }^{\mathrm{w1}} \mathrm{w}^{\mathrm{w}}$ or a single intravenous bolus dose of $80 \mathrm{mg} .^{\text {w3 }}$ In the treatment group doses ranged from 600$3400 \mathrm{mg} /$ day in the studies that evaluated frusemide in established acute renal failure. In one of these studies, ${ }^{\mathrm{w} 6}$ the control group also received one dose of frusemide $(1 \mathrm{~g})$ while the treatment group received prolonged frusemide infusion (3.4 $\mathrm{g} /$ day) until the serum creatinine level fell spontaneously to less than $300 \mu \mathrm{mol} / \mathrm{l}$. Two different doses of frusemide were assessed in two separate treatment groups in one study. ${ }^{\mathrm{w8}}$ The criteria to initiate dialysis were described in only three studies. ${ }^{\text {w5-w7 }}$ Jadad scores ranged from 1 to 5 (mean 2.6). Allocation concealment was adequate in four studies. ${ }^{\text {w1-w3 }}{ }^{\text {w7 }}$ Double blinding was used in four studies. $^{\mathrm{w1}} \mathrm{w}^{2} \mathrm{w}^{\mathrm{w} 7}$ Three studies reported the proportion of patients who were randomised but lost to follow-up; all less than $5 \%$. The table lists the characteristics of the included studies.

No significant heterogeneity was found for in-hospital mortality and ototoxicity but heterogeneity was significant for the other outcomes. No significant reduction after frusemide treatment was found for in-hospital mortality (relative risk 1.11, $95 \%$ confidence interval 0.92 to $1.33, \mathrm{P}=0.28, \mathrm{I}^{2}=0 \% \mathrm{l}$ fig 2 ), risk for requiring renal replacement therapy or dialysis $(0.99,0.80$ to $1.22, \mathrm{P}=0.91, \mathrm{I}^{2}=64.2 \%$; fig 2 ), number of dialysis sessions required (weighted mean difference -0.48 sessions, -1.45 to $0.50, \mathrm{P}=0.34, \mathrm{I}^{2}=0 \%$; fig 3 ), or proportion of patients with persistent oliguria (urine output $<500 \mathrm{ml} /$ day; $0.54,0.18$ to 1.61 , $\mathrm{P}=0.27, \mathrm{I}^{2}=90.8 \%$; fig 4). Regardless of whether frusemide was

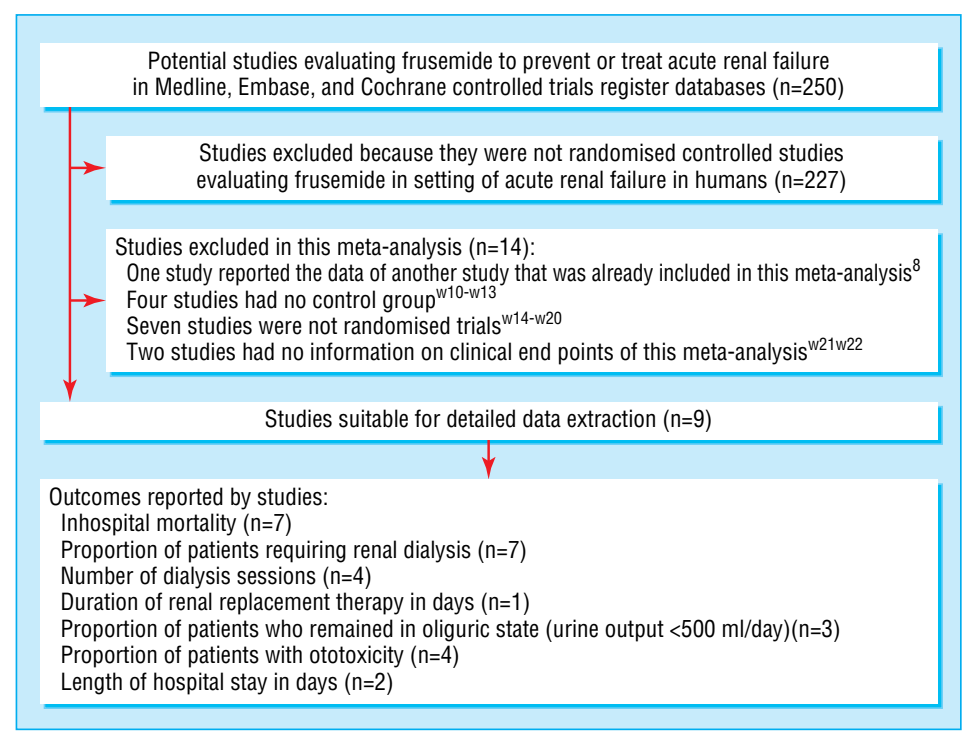

Fig 1 Flow of studies in meta-analysis 


\begin{tabular}{|c|c|c|c|c|}
\hline Study & Participants & Interventions & Outcomes & Study quality* \\
\hline Lassniggw1 $^{\mathrm{w} 1}$ & $\begin{array}{l}126 \text { adults with serum creatinine } \\
\text { levels }<177 \mu \mathrm{mol} / \mathrm{l} \text { who underwent } \\
\text { elective cardiac surgery }\end{array}$ & $\begin{array}{l}\text { Control group }(\mathrm{n}=40) \text { normal saline } \\
\text { infusion } 2.5 \mathrm{ml} / \mathrm{h} \text {; frusemide group } \dagger \\
(\mathrm{n}=41) 2.5 \mathrm{mg} / \mathrm{h} \text { infusion; study drug } \\
\text { started after induction of anaesthesia } \\
\text { until } 48 \text { hours after surgery or } \\
\text { discharge from intensive care unit }\end{array}$ & $\begin{array}{l}\text { Mortality, proportion of patients } \\
\text { requiring dialysis, and length of } \\
\text { hospital stay }\end{array}$ & $\begin{array}{l}\text { Adequate allocation concealment, } \\
\text { double blinded, } 2.4 \% \text { of patients lost to } \\
\text { follow-up, not by intention to treat } \\
\text { analysis, Jadad score } 5\end{array}$ \\
\hline Hager $^{\text {W2 }}$ & $\begin{array}{l}121 \text { adults who underwent major } \\
\text { abdominal, chest, or vascular } \\
\text { surgery with mean serum creatinine } \\
\text { concentrations before surgery } \\
93-105 \mu \mathrm{mol} / \mathrm{l}\end{array}$ & $\begin{array}{l}\text { Control group }(\mathrm{n}=59) 5 \% \text { dextrose } 1.4 \\
\mathrm{ml} / \mathrm{h} \text {; frusemide group }(\mathrm{n}=62) 1 \mathrm{mg} / \mathrm{h} \\
\text { infusion; study drug started after } \\
\text { admission to intensive care unit and } \\
\text { continued to discharge }\end{array}$ & $\begin{array}{l}\text { Mortality, proportion of patients } \\
\text { requiring dialysis, and length of } \\
\text { hospital stay }\end{array}$ & $\begin{array}{l}\text { Adequate allocation concealment, } \\
\text { double blinded, losses to follow-up not } \\
\text { reported, unclear whether results were } \\
\text { analysed by intention to treat, Jadad } \\
\text { score } 4\end{array}$ \\
\hline Solomon ${ }^{\text {w3 }}$ & $\begin{array}{l}78 \text { adults with chronic renal } \\
\text { insufficiency (serum creatinine level } \\
>140 \mu \mathrm{mol} / \mathrm{l} \text { ) who underwent cardiac } \\
\text { angiography (mean serum creatinine } \\
\text { levels } 186 \mu \mathrm{mol} / \mathrm{l} \text { in both groups } \\
\text { before angiography }\end{array}$ & $\begin{array}{l}\text { Control group }(\mathrm{n}=28) \text { and frusemide } \\
\text { group } \neq(\mathrm{n}=25) 0.45 \% \text { saline } 1 \mathrm{ml} / \mathrm{kg} / \mathrm{h} \\
\text { started } 12 \text { hours before angiography } \\
\text { and continued } 12 \text { hours after } \\
\text { angiography; frusemide group also } \\
\text { given } 80 \mathrm{mg} \text { frusemide intravenously } \\
30 \text { minutes before angiography }\end{array}$ & $\begin{array}{l}\text { Proportion of patients requiring } \\
\text { dialysis }\end{array}$ & $\begin{array}{l}\text { Adequate allocation concealment, } \\
\text { unsure blinding, losses to follow-up not } \\
\text { reported, unclear whether results were } \\
\text { analysed by intention to treat, Jadad } \\
\text { score } 2\end{array}$ \\
\hline Shilliday ${ }^{\mathrm{w} 4}$ & $\begin{array}{l}96 \text { adults with acute renal failure } \\
\text { (serum creatinine level }>180 \mu \mathrm{mol} / \mathrm{l} \\
\text { and mean creatinine clearance } 7-8 \\
\mathrm{ml} / \mathrm{min} \text { ) not due to prerenal or } \\
\text { post-renal causes who had not } \\
\text { received frusemide in preceding } 48 \\
\text { hours }\end{array}$ & $\begin{array}{l}\text { Control group }(\mathrm{n}=30 \text { ) placebo (not } \\
\text { defined) intravenous infusion over } 1 \\
\text { hour every six hours to } 21 \text { days; } \\
\text { frusemide group§ ( } \mathrm{n}=32 \text { ) intravenous } 3 \\
\mathrm{mg} / \mathrm{kg} \text { every six hours reduced to } 2 \\
\mathrm{mg} / \mathrm{kg} \text {, then } 1 \mathrm{mg} / \mathrm{kg} \text { (if the serum } \\
\text { creatinine level fell) and stopped when } \\
\text { renal function recovered; all patients } \\
\text { also received dopamine } 2 \mu \mathrm{gg} / \mathrm{kg} / \mathrm{min} \\
\text { and mannitol } 20 \% 100 \mathrm{ml} \text { every six } \\
\text { hours. Mannitol was stopped on day } 3 \\
\text { if patient remained oliguric }\end{array}$ & $\begin{array}{l}\text { Mortality, proportion of patients } \\
\text { requiring dialysis and with } \\
\text { ototoxicity, and duration (mean } \\
\text { (SD) days) of dialysis needed }\end{array}$ & $\begin{array}{l}\text { Allocation concealment unclear, double } \\
\text { blinded, } 4.2 \% \text { lost to follow-up, analysis } \\
\text { not by intention to treat, Jadad score } 3\end{array}$ \\
\hline Kleinknecht"w5 & $\begin{array}{l}66 \text { adults with oliguric acute renal } \\
\text { failure (urine output }<500 \mathrm{~m} / \text { day) } \\
\text { but without chronic renal failure }\end{array}$ & $\begin{array}{l}\text { Control group ( } \mathrm{n}=33 \text { ) placebo (not } \\
\text { defined). Frusemide group ( } \mathrm{n}=33 \text { ) } 3 \\
\mathrm{mg} / \mathrm{kg} \text { every four hours to maintain } \\
\text { urine output between } 20 \mathrm{ml} / \mathrm{h} \text { and } 100 \\
\mathrm{ml} / \mathrm{h} \text { and } 6 \mathrm{mg} / \mathrm{kg} \text { if diuresis remained } \\
<20 \mathrm{ml} / \mathrm{h}, 1.5 \mathrm{mg} / \mathrm{kg} \text { if diuresis between } \\
100 \mathrm{ml} / \mathrm{h} \text { and } 150 \mathrm{ml} / \mathrm{h} \text {, and none if } \\
\text { diuresis }>150 \mathrm{ml} / \mathrm{h} \text {. Maximal daily dose } \\
\text { was } 1200 \mathrm{mg} \text {. Urine output replaced by } \\
5 \% \text { dextrose with saline } 6 \mathrm{~g} / \mathrm{l} \text { and } \\
\text { potassium chloride } 1.5 \mathrm{~g} / \mathrm{l}\end{array}$ & $\begin{array}{l}\text { Mortality, proportion of patients } \\
\text { requiring dialysis and with } \\
\text { deafness or tinnitus, number of } \\
\text { dialysis sessions required (to } \\
\text { maintain serum urea level }<71 \\
\text { mmol/l), and proportion of } \\
\text { patients remaining oliguria ( }<500 \\
\text { ml/day) }\end{array}$ & $\begin{array}{l}\text { Allocation concealment not clear, } \\
\text { blinding not clear, losses to follow-up } \\
\text { not reported, unclear whether the } \\
\text { results were analysed by intention to } \\
\text { treat, Jadad score } 1\end{array}$ \\
\hline Cantarovich $^{w 7}$ & $\begin{array}{l}338 \text { adults with acute renal failure } \\
\text { (plasma urea level }>30 \mathrm{mmol} / \mathrm{l} \text { and } \\
\text { oligoanuric for } 48 \text { hours) and } \\
\text { requiring renal replacement therapy }\end{array}$ & $\begin{array}{l}\text { Control group ( } \mathrm{n}=164 \text { ) matched placebo } \\
\text { (not defined); frusemide group ( } \mathrm{n}=166 \text { ) } \\
\text { intravenous } 25 \mathrm{mg} / \mathrm{kg} / \text { day infusion, } \\
\text { changed to oral } 35 \mathrm{mg} / \mathrm{kg} / \text { day when } \\
\text { tolerated. All drugs given after dialysis } \\
\text { if intermittent dialysis was used. } \\
\text { Weaned to } 20 \mathrm{mg} / \mathrm{kg} / \text { day orally or } 15 \\
\mathrm{mg} / \mathrm{kg} / \mathrm{day} \text { intravenously then } 10 \\
\mathrm{mg} / \mathrm{kg} / \mathrm{day} \text { both orally and intravenously } \\
\text { and then } 5 \mathrm{mg} / \mathrm{kg} / \text { day before } \\
\text { discontinuation when renal function } \\
\text { recovered }\end{array}$ & $\begin{array}{l}\text { Mortality, proportion of patients } \\
\text { with deafness or tinnitus, number } \\
\text { of dialysis sessions required (to } \\
\text { maintain serum creatinine level } \\
<200 \mu \mathrm{mol} / \mathrm{l})\end{array}$ & $\begin{array}{l}\text { Adequate allocation concealment, } \\
\text { double blinded, } 2.4 \% \text { losses to } \\
\text { follow-up, analysis by intention to treat, } \\
\text { Jadad score } 5\end{array}$ \\
\hline Cantarovich $^{\text {w8 }}$ & $\begin{array}{l}47 \text { adults with acute renal failure } \\
\text { with urine output }<400 \mathrm{ml} / \text { day and } \\
\text { with clear diagnosis of acute renal } \\
\text { failure and no response to mannitol } \\
60 \mathrm{~g} \text { within } 24 \text { hours }\end{array}$ & $\begin{array}{l}\text { Control group ( } n=13 \text { ) conventional } \\
\text { treatment (not defined); frusemide } \\
\text { group } 1 \text { ( } n=19 \text { ) fixed dose } 600 \mathrm{mg} / \text { day } \\
\text { until diuresis }>2000 \mathrm{ml} / \text { day; frusemide } \\
\text { group } 2(n=15) \text { progressive dose, } \\
\text { geometric progressionfl of frusemide } \\
\text { from } 100 \mathrm{mg} \text { (over } 30 \text { minutes) to } \\
3200 \mathrm{mg} / \text { day (over } 10 \text { hours) }\end{array}$ & $\begin{array}{l}\text { Mortality, number of dialysis } \\
\text { sessions required, proportion of } \\
\text { patients who remained oliguric } \\
(<400 \mathrm{ml} / \text { day })\end{array}$ & $\begin{array}{l}\text { Allocation concealment not clear, no } \\
\text { blinding, } \\
\text { losses to follow-up not reported, } \\
\text { unclear whether the results were } \\
\text { analysed by intention to treat, Jadad } \\
\text { score } 1\end{array}$ \\
\hline Brown ${ }^{w 6}$ & $\begin{array}{l}56 \text { adults with acute renal failure not } \\
\text { due to obstruction or dehydration; } \\
\text { patients were not necessarily } \\
\text { oligoanuric }\end{array}$ & $\begin{array}{l}\text { Control group }(\mathrm{n}=28) \text { intravenous } \\
\text { frusemide } 4 \mathrm{mg} / \mathrm{min} \text { for four hours } \\
\text { (total } 1 \mathrm{~g}) \text {; frusemide group }(\mathrm{n}=28) \\
\text { intravenous } 4 \mathrm{mg} / \mathrm{min} \text { for four hours } \\
\text { (total } 1 \mathrm{~g} \text { ) followed by } 2 \mathrm{mg} / \mathrm{min} \\
\text { infusion or oral frusemide } 1 \mathrm{~g} \text { three } \\
\text { times daily to maintain urine output at } \\
150 \text { to } 200 \mathrm{ml} / \mathrm{h} \text { until serum creatinine } \\
\text { level }<300 \mu \mathrm{mol} / / \text { without dialysis }\end{array}$ & $\begin{array}{l}\text { Mortality, proportion of patients } \\
\text { requiring dialysis and with } \\
\text { deafness or tinnitus, number of } \\
\text { dialysis sessions required (to } \\
\text { maintain serum urea level }<30 \\
\mathrm{mmol} / / \text { and creatinine level }<800 \\
\mu \mathrm{mol} / \mathrm{l}) \text {, and proportion of patients } \\
\text { remaining or converted to oliguria } \\
<500 \mathrm{ml} / \text { day }\end{array}$ & $\begin{array}{l}\text { Allocation concealment not adequate, } \\
\text { no blinding, losses to follow-up not } \\
\text { reported, unclear whether results were } \\
\text { analysed by intention to treat, Jadad } \\
\text { score } 1\end{array}$ \\
\hline Karayannopoulos ${ }^{\text {w9 }}$ & $\begin{array}{l}20 \text { adults with acute renal failure or } \\
\text { acute on chronic renal failure. } \\
\text { Patients not described except age } \\
\text { and diagnoses matched between } \\
\text { control and treatment groups }\end{array}$ & $\begin{array}{l}\text { Control group }(\mathrm{n}=10) \text { conventional } \\
\text { treatment without frusemide (not } \\
\text { described); frusemide group }(\mathrm{n}=10) 1 \mathrm{~g} \\
\text { initially and increased to } 3 \mathrm{~g} \text { over seven } \\
\text { days if no response }\end{array}$ & $\begin{array}{l}\text { Proportion of patients requiring } \\
\text { dialysis }\end{array}$ & $\begin{array}{l}\text { Allocation concealment not clear, no } \\
\text { blinding, losses to follow-up not } \\
\text { reported, unclear whether results were } \\
\text { analysed by intention to treat, Jadad } \\
\text { score } 1\end{array}$ \\
\hline
\end{tabular}

*Allocation concealment, blinding, proportion lost to follow-up, intention to treat analysis, and Jadad score (range 0-5, higher scores indicating better quality).

†Third treatment group (dopamine infusion, $n=42$ ) not included in meta-analysis.

†Third treatment group (mannitol with $0.45 \%$ saline, $n=25$ ), not included in meta-analysis.

$\S$ Third treatment group (torasemide, $\mathrm{n}=30$ ), not included in meta-analysis.

INo details on how geometric progression criteria were applied. 
used to prevent or to treat acute renal failure no significant difference was found on the effects of mortality (relative risk ratio 2.10, 95 confidence interval 0.67 to $6.63, \mathrm{P}=0.20)$ and the proportion of patients requiring dialysis $(4.12,0.46$ to 37.2 , $\mathrm{P}=0.21$ ). High dose frusemide (range 1-3.4 g daily) was associated with a suggestion of an increased risk of temporary deafness and tinnitus (relative risk 3.97, 95\% confidence interval 1.00 to $15.78, \mathrm{P}=0.05, \mathrm{I}^{2}=0 \%$; fig 4 ). The length of hospital stay was reported in two preventive studies. ${ }^{\mathrm{w} 1 \mathrm{w} 2}$ Frusemide treatment was associated with an increase in hospital stay (weighted mean difference 3.57 days, $95 \%$ confidence interval 0.02 to 7.12 , $\left.\mathrm{P}=0.049, \mathrm{I}^{2}=0 \%\right)$. None of the studies reported a formal cost effectiveness analysis. The funnel plot showed a small possibility of publication bias, with absence of small studies showing a reduction in mortality after frusemide treatment (fig 5 ).

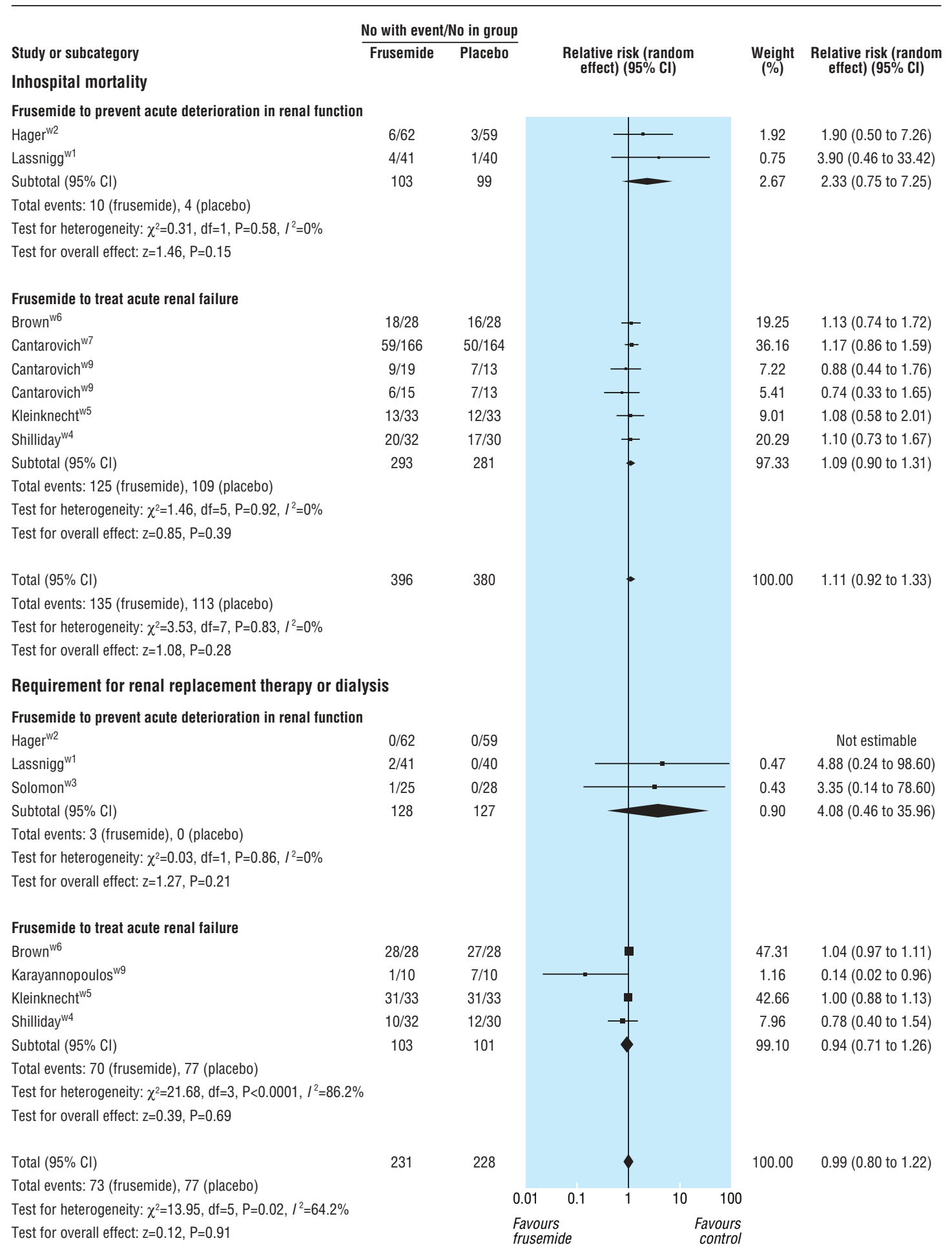

Fig 2 Effect of frusemide on in-hospital mortality and proportion of patients requiring renal replacement therapy or dialysis 


\section{Sensitivity analyses}

The magnitude and significance of the results were not changed after excluding one study that used a single bolus of frusemide in the control group ${ }^{\mathrm{w} 6}$ or studies without adequate allocation concealment. ${ }^{\mathrm{w}-\mathrm{w} 6 \mathrm{w} 8 \mathrm{w} 9}$

\section{Discussion}

Meta-analysis showed that frusemide is not effective in the prevention and treatment of acute renal failure in adults. Fruse- mide did not reduce in-hospital mortality, the requirement for dialysis, the number of dialysis sessions required until recovery of renal function, the proportion of patients remaining oliguric (urine output $<500 \mathrm{ml} /$ day), and the length of hospital stay. Furthermore, high doses may be associated with an increased risk of ototoxicity.

Frusemide has been shown to reduce renal tubular damage in experimental settings and as such has been widely used to prevent or treat acute renal failure. It has been argued that frusemide, especially at high doses, may convert oliguric acute renal

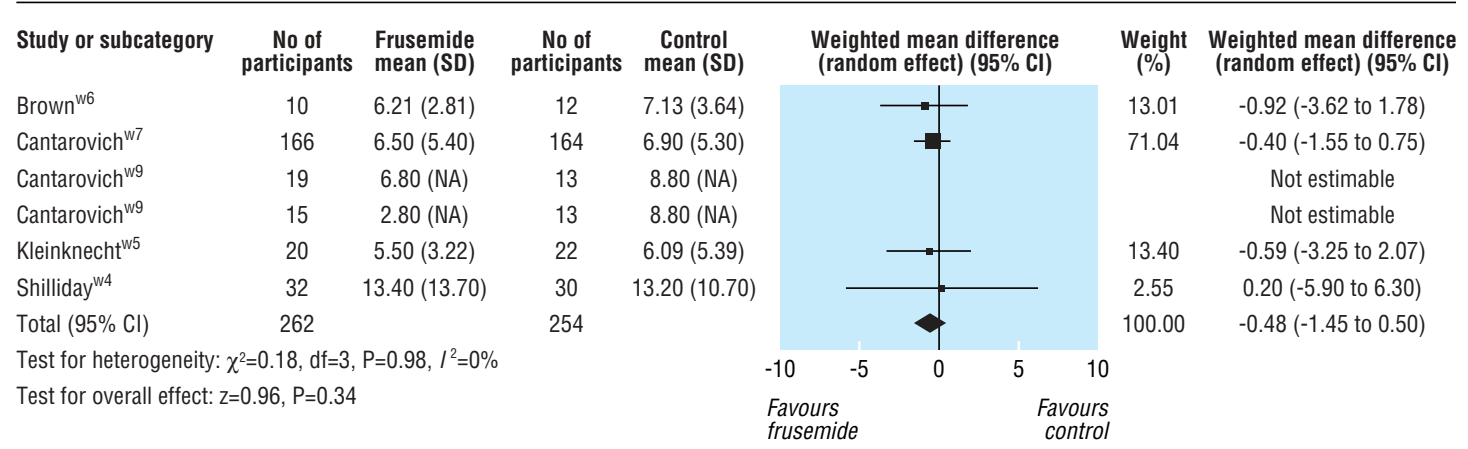

Fig 3 Number of dialysis sessions required after frusemide or control treatments. NA=not available

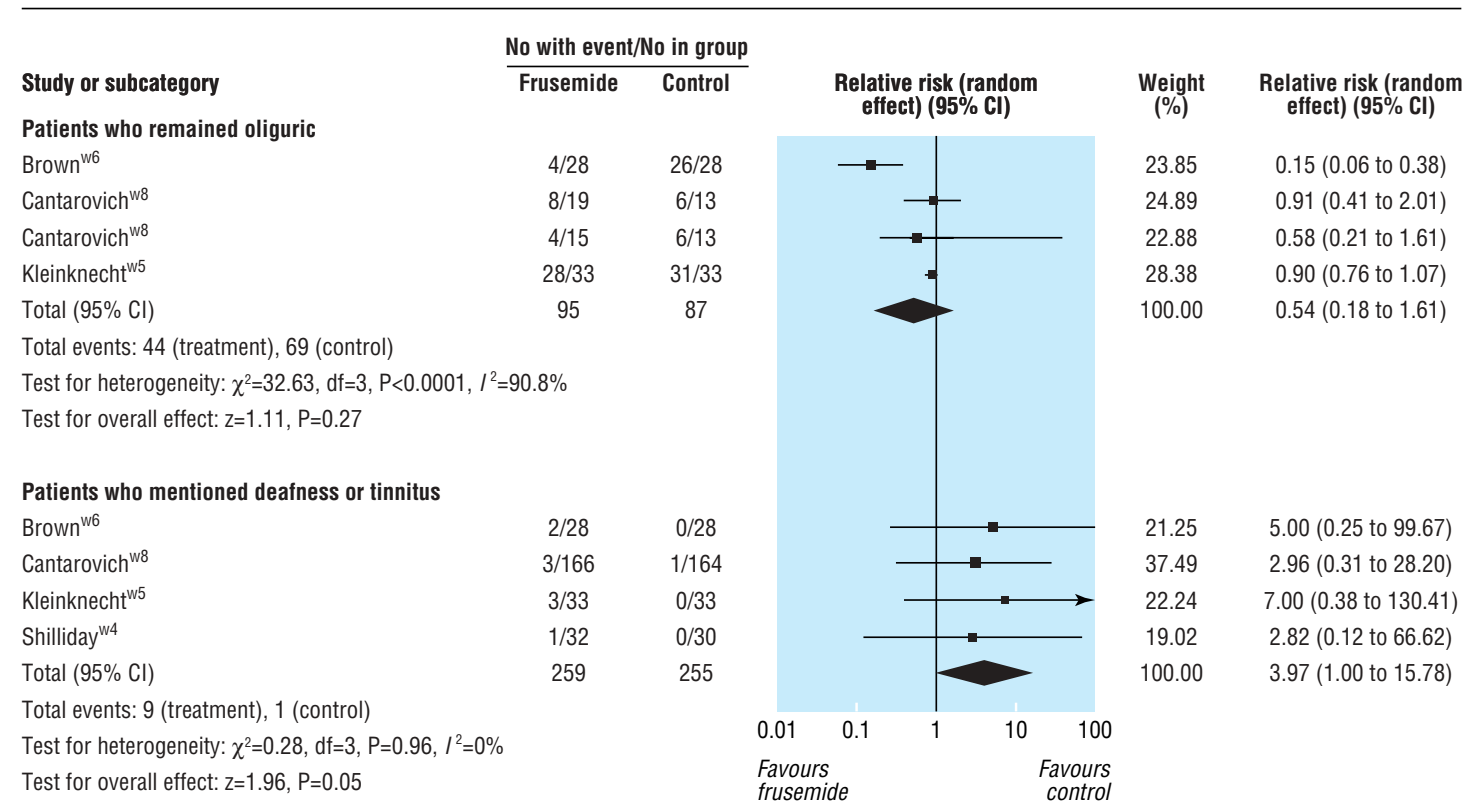

Fig 4 Proportion of patients remaining oliguric (urine output $<500 \mathrm{ml} /$ day) after frusemide or control treatments and those mentioning tinnitus or deafness

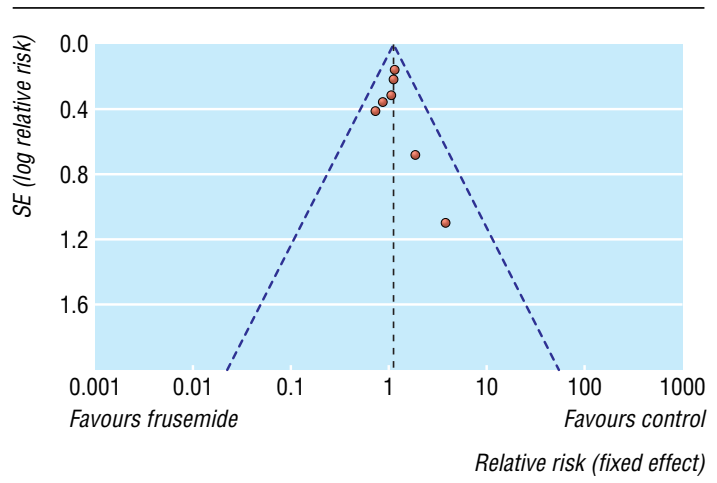

Fig 5 Funnel plot showing possibility of small publication bias (broken lines show overall effect and 95\% confidence intervals) 


\section{What is already known in this topic}

Frusemide, a potent loop diuretic, can induce diuresis in some patients with acute renal impairment

\section{What this study adds}

Frusemide is not associated with any clinical benefits when used to prevent and treat acute renal failure in adults

High doses of frusemide may be associated with an increased risk of ototoxicity

failure to non-oliguric acute renal failure and thus reduce the requirement for dialysis. ${ }^{\mathrm{w} 7}{ }^{\mathrm{w} 14}$ This meta-analysis did not show these potential benefits. As frusemide is largely excreted unchanged in the urine and influences tubular reabsorption from the luminal side, it is the urinary excretion of the drug, not its plasma concentration, that determines the efficacy of its diuretic action. ${ }^{11}{ }^{12}$ Non-oliguric acute renal failure is in general associated with a better prognosis than oliguric acute renal failure $^{5}$ and studies have shown that patients who have diuretic responses to frusemide have less severe acute renal failure. ${ }^{\mathrm{w4}}$ Therefore a positive diuretic response to frusemide may indicate that patients have a milder form of acute renal failure rather than frusemide being capable of converting a more severe form of acute renal failure to a less severe form and improve the outcome. ${ }^{\mathrm{w} 4}{ }^{13}$ Our results agree with this hypothesis.

Frusemide, especially at high doses, is associated with important side effects. Previous observational studies have produced conflicting results about frusemide's association with mortality. ${ }^{2} 6$ We did not find any significant increase in mortality after frusemide treatment. High doses of frusemide (1-3.4 g daily) may, however, be associated with an increased risk of ototoxicity. Frusemide is primarily excreted by the kidneys and high doses can increase its serum concentration substantially in acute renal failure $^{12 \text { w8 }}$ and hence the higher risk of ototoxicity. Most of the symptoms of ototoxicity reported by the patients in the pooled studies resolved after treatment was stopped. Nevertheless, sedated and ventilated patients with acute renal failure in the intensive care unit would not be able to communicate their symptoms of ototoxicity and, as such, high doses of frusemide potentially may be more dangerous.

\section{Limitations of the study}

Firstly, meta-analyses are prone to bias, and study quality can affect the direction and magnitude of treatment effect. In the pooled studies only four trials had adequate allocation concealment $\mathrm{t}^{\mathrm{w1-w3} \mathrm{w}^{\mathrm{w}}}$ and four had a Jadad score of 3 or more. ${ }^{\mathrm{w1} \text { w2 } \mathrm{w4}}$ w7 The magnitude and direction of the results was not changed in sensitivity analysis by including only the four studies with adequate allocation concealment. Furthermore, the number of patients included in this meta-analysis may be inadequate to exclude small but significant clinical benefits of frusemide. With the sample size of this meta-analysis (204 patients when considering requirement for renal dialysis as an end point in established acute renal failure), a positive protective effect of frusemide on the risk for requiring dialysis can only be shown if the associated relative risk reduction exceeds $30 \%$. If frusemide can reduce the relative risk for requiring dialysis by only $20 \%$, a sample size of 400 patients would be required to show such an effect if the baseline risk for requiring dialysis is $70 \%$ in the control group. Secondly, with the absence of small studies showing a reduction in mortality after the use of frusemide small publication bias was possible (fig 5). This apparent bias is unusual because it implies a lack of published studies with positive results. The asymmetrical shape of the funnel plot could be the result of the small number of studies included in this meta-analysis rather than true publication bias. ${ }^{14}$ Finally, although the results of this meta-analysis were largely consistent across the studies included, significant differences were found in how frusemide was given. The benefits of a particular dose or mode of administration remain uncertain because of the small number of studies included in this meta-analysis.

Contributors: KMH and DJS searched the literature search, extracted the data, and drafted the manuscripts. KMH carried out the statistical analyses. DJS initiated the idea of the meta-analysis. KMH is guarantor.

Funding: Department of Intensive Care, Royal Perth Hospital.

Competing interests: None declared.

Ethical approval: Not required.

1 Uchino S, Kellum JA, Bellomo R, Doig GS, Morimatsu H, Morgera S, et al. Acute renal failure in critically ill patients: a multinational, multicenter study. JAMA 2005;294:813-8.

Uchino S, Doig GS, Bellomo R, Morimatsu H, Morgera S, Schetz M, et al. Diuretics and mortality in acute renal failure. Crit Care Med 2004;32:1669-77.

3 Brezis M, Agmon Y, Epstein FH. Determinants of intrarenal oxygenation. I. Effects of Brezis M, Agmon Y, Epstein FH. Determinants of
diuretics. Am J Physiol 1994;267(6 Pt 2):F1059-62.

4 Heyman SN, Rosen S, Epstein FH, Spokes K, Brezis ML. Loop diuretics reduce hypoxic damage to proximal tubules of the isolated perfused rat kidney. Kidney Int 1994;45:981-5.

5 Frankel MC, Weinstein AM, Stenzel KH. Prognostic patterns in acute renal failure: the New York Hospital, 1981-1982. Clin Exp Dial Apheresis 1983;7:145-67.

6 Mehta RL, Pascual MT, Soroko S, Chertow GM, PICARD Study Group. Diuretics, mortality, and nonrecovery of renal function in acute renal failure. JAMA 2002;288:254753.

7 Jadad AR, Moore RA, Carroll D, Jenkinson C, Reynolds DJ, Gavaghan DJ, et al. Assessing the quality of reports of randomized clinical trials: is blinding necessary? Control Clin Trials 1996;17:1-12.

8 Ganeval D, Kleinknecht D, Gonzales-Duque LA. High-dose frusemide in renal failure [Letter.] BMJ 1974;290:244-5.

9 Altman DG, Bland JM. Interaction revisited: the difference between two estimates. BMJ 2003;326:219.

10 Higgins JP, Thompson SG, Deeks JJ, Altman DG. Measuring inconsistency in meta-analyses. BMJ 2003;327:557-60.

11 Wittner M, Di Stefano A, Wangemann P, Greger R. How do loop diuretics act? Drugs 1991;41(suppl 3):1-13.

12 Miyazaki H, Hirai J, Taneike T. The pharmacokinetics and pharmacodynamics of furosemide in anesthetized dogs with normal and experimentally decreased renal function. Nippon Juigaku Zasshi 1990;52:265-73.

13 Ho KM, Walters S, Faulke D, Liang J. Clinical predictors of acute renal replacement therapy in critically ill patients with acute renal impairment. Crit Care Resusc 2003:5:97-102.

14 Terrin N, Schmid CH, Lau J. In an empirical evaluation of the funnel plot, researchers could not visually identify publication bias.J Clin Epidemiol 2005;58:894-901. (Accepted 12 June 2006)

doi $10.1136 /$ bmj.38902.605347.7C

Intensive Care Unit, Royal Perth Hospital, Perth, Western Australia 6000

Kwok M Ho consultant

David J Sheridan resident medical officer

Correspondence to: K M Ho kwok.ho@health.wa.gov.au 